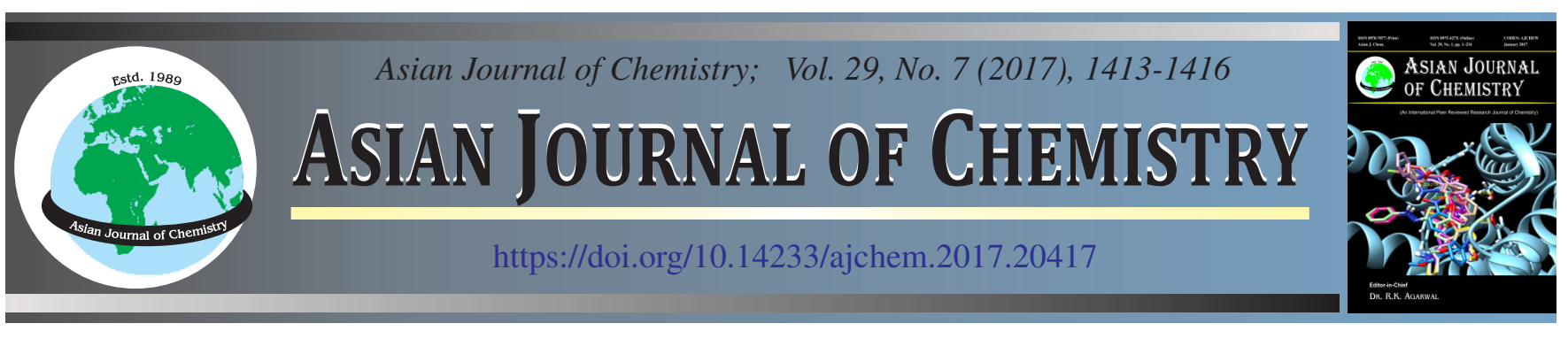

\title{
Expression of Cytosolic and Non-Cytosolic Carbonic Anhydrase Enzymes from Bovine Large Intestine
}

\author{
FATMA ErgüN ${ }^{1}$ and NAZAN Demir ${ }^{2, *}$
}

${ }^{1}$ Ahi Evran University, School of Health, Kirsehir, Turkey

${ }^{2}$ Department of Chemistry, Faculty of Sciences, Mugla University, 48000 Mugla, Turkey

*Corresponding author: Fax: +90 252 2360948; Tel: +90 252 2314439; E-mail: demirn@yahoo.com

\section{INTRODUCTION}

Carbonic anhydrase (CA; E.C.4.2.1.1), containing $\mathrm{Zn}^{2+}$, is a ubiquitous metalloenzyme known for catalyzing the reversible hydration/dehydration reactions of carbon dioxide, which are crucial for many homeostatic processes such as acid base balance and gas transport [1].

The enzyme was first isolated from mammalian erythrocytes [2] and then carbonic anhydrase have been purified and characterized from plants, bacteria [3-9], human most mammalian red blood cells [3], bovine bone [10], Escherichia coli $[10,11]$ many tissues and other biological materials [10]. It's localization is largely cytosol and partly cell membrane. The molecular weights differ from cell to cell of the same species and from one organism to another and were reported as 30.000, 36.000, $180.000,66.000,54.000$ for human erythrocyte, for human erythrocyte membranes, for parsley, for human kidney and for rabbit erythrocytes respectively $[3,12,13]$. The apparent molar mass was initially reported to be 68.000 [6], but more recent purification by this method yielded an inactive polypeptide with a molar mass of 34.400 on SDS-PAGE [6]. So far, eleven isozymes of carbonic anhydrase and carbonic anhydraserelated proteins have been identified in mammals [12-15]. Some are expressed in almost all tissues, while others are tissue or organ specific. Four of them are cytosolic isozymes (I, II, III and VII), four of them are membrane bound (IV, IX, XII and XIV), two of them are present in mitochondria (VA and VB) and one of them is a secretory isozyme (VI) [16]. The first membrane-associated carbonic anhydrase purified to homogeneity was obtained from bovine lung [4]. After several years, a different type of purification of a membrane-bound carbonic anhydrase from human kidney membranes was reported [5,6]. It has also been expressed that membrane-bound carbonic anhydrases is in osteoclasts [1]. Membrane-bound carbonic anhydrase IV isozyme is widely expressed in most species [1] and has been thought to play a role in the regulation of acid-base balance in the kidney. The other membrane-bound carbonic anhydrase IX isozyme, in turn, is expressed in many cancers but also in normal gastrointestinal tract tissues [1]. In brain, carbonic anhydrase has an important role in the neuronglia metabolic relationships because it regulates anion and acid base balance of brain cells and extracellular cerebrospinal fluids [4-6]. Immunohistochemically, carbonic anhydrase IV was found to localize in the distal small and the large intestine to the apical (luminal) side of the epithelial plasma membranes. The regional, cellular and subcelluler localizations of carbonic anhydrase IV in the gut epithelium are consistent with proposed physiologic roles for gastrointestinal carbonic anhydrase. 
Carbonic anhydrase activity participates in ion and water transport in both the ileum and large intestine [17]. It has been thought that enzyme is bonded weakly (peripheral) to large intestine, dissolved to cytoplasma and could be bonded hardly (integral) to membrane. Consequently, the purification of carbonic anhydrase enzyme from large intestine in four steps that are outer peripheral, cytosolic, inner peripheral and integral was aimed. There is defining conditions in which these enzymes could be shown maximum activity and determination of molecular weights in this investigation.

\section{EXPERIMENTAL}

Homogenate of large intestine: Large intestine was kept in physiological serum and then washed with $0.09 \% \mathrm{NaCl}$ solvent. This procedure was applied until erythrocyte was completly removed from the medium.

Homogenate for outer peripheral carbonic anhydrase enzyme: Bovine large intestine was added to $300 \mathrm{~mL}$ of $1 \mathrm{M}$ $\mathrm{KCl}$ solution and mixed by vortexing. It was then centrifuged by cooling centrifuge in $12.186 \times \mathrm{g}$ for $30 \mathrm{~min}$. Precipitate and supernatant were separated. Separated supernatant was washed with $\mathrm{CCl}_{4}$ by this way lipids were extracted. After that $\mathrm{pH}$ of homogenate was adjusted to 8,7 with solid Tris. By this way homogenate was suited in situation for applying column [11].

Homogenate for cytosolic carbonic anhydrase enzyme: First remaining precipitate from the former step of centrifuge was washed thoroughly with $1 \mathrm{M} \mathrm{KCl}$. It was taken in $250 \mathrm{~mL}$

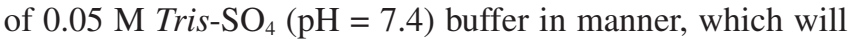
have $2 \mathrm{~mL}$ for each gram after solution procedure and it was experienced to ultrasonic sound wave in ultrasonic dismembrator for $4 \mathrm{~h}$. After that it was centrifuged by cooling centrifuge in $12.186 \times \mathrm{g}$ for $30 \mathrm{~min}$. Lipids were extracted by washing the supernatant with $\mathrm{CCl}_{4}$ while precipitate is being separated for inner peripheral proteins and it was prepared for affinity column by bringing $\mathrm{pH}$ to 8.7 with solid Tris buffer [11].

Homogenate for inner peripheral carbonic anhydrase enzyme: Remaining precipitate from former step of centrifuge was washed by $0.05 \mathrm{M}$ Tris $-\mathrm{SO}_{4}(\mathrm{pH}=7.4)$ buffer after that itwas taken into solvent of $300 \mathrm{~mL} 1 \mathrm{M} \mathrm{KCl}$ and mixed by vortexing. It was centrifuged after mixing in low velocity for $2 \mathrm{~h}$ and then supernatant and precipitate was separated each other. Precipitate was kept for the separation of integral proteins. First supernatant was washed with $\mathrm{CCl}_{4}$ after $\mathrm{pH}$ was calibrated to 8.7 [11].

Homogenate for integral carbonic anhydrase enzyme: Remaining precipitate from the former step was added in 0.05 M Tris- $\mathrm{SO}_{4}(\mathrm{pH}=7.4)$ which is containing $300 \mathrm{~mL} 1 \%$ Triton $\mathrm{X}-100$. The sample was experienced to ultrasonic sound wave in ultrasonic dismembrator for $4 \mathrm{~h}$. Then precipitate was thrown away by centrifuging. However supernatant was tried to clean from all detergent excess by making dialysis to pure water for 2 days and than to $0.05 \mathrm{M}$ Tris- $\mathrm{SO}_{4}(\mathrm{pH}=7.4)$ for 1 day. Later probable lipids were removed by washing $100 \mathrm{~mL} \mathrm{CCl}_{4} . \mathrm{pH}$ of homogenate was brought to 8.7 by solid Tris- $\mathrm{SO}_{4}$ homogenate was brought in lading statute to column.

Application of homogenates, which is prepared of bovine large intestine and purifying of carbonic anhydrase enzyme: Affinity gel was prepared on Sepharose-4B matrix. Tyrosine was picked on as covalent after activated sepharose$4 \mathrm{~B}$ by $\mathrm{CNBr}$. Then sulphanilamide was clamped to tyrosine by diazotization. In this point tyrosine was formed to stretch out of affinity gel however sulphanilamide was formed the part which is bonded to enzyme specificaly. This affinity column has been successfuly used in purifiying carbonic anhydrase enzyme in high rate. Same column has been used respectively in purifiying inner peripheral, cytosolic, outer peripheral and integral proteins. It has been checked that the column is balanced completely before application of homogenate. The carbonic anhydrase has also been purified from bovine erythrocyte by affinity chromatography [9] for using and comparing as protein in electrophore.

Protein determination: After scanning at $280 \mathrm{~nm}$, the tubes with have absorbance were pooled and a quantitative protein determination was done by the Coomassie Brillant Blue G-250 method [9].

Enzyme activity determination: Esterase and hydratase activities were determined the isoenzyme.

$\mathrm{CO}_{2}$-Hydratase activity determination: Two $\mathrm{mL}$ of veronal buffer (pH: 8.2), $0.2 \mathrm{~mL}$ of brome thymol blue $(0.004$ $\%$ ), $0.8 \mathrm{~mL}$ of diluted enzyme and $2 \mathrm{~mL}$ of a $\mathrm{CO}_{2}$ solution (saturated at $0{ }^{\circ} \mathrm{C}$ ) were mixed. The time $\left(\mathrm{t}_{\mathrm{c}}\right)$ interval was determined between addition of $\mathrm{CO}_{2}$ solution and the occurrence of a yellow-green colour. The same interval was recorded without enzyme solution $\left(\mathrm{t}_{\mathrm{o}}\right)$. The activity was calculated from the equation [18].

\section{Wilbur-Anderson Unit $=\left(t_{\mathrm{o}}-\mathrm{t}_{\mathrm{c}}\right) / \mathrm{t}_{\mathrm{c}}$}

Determination of esterase activity: The principle of this determination is that the substrate of carbonic anhydrase ( $p$ nitrophenyl acetate) is hydrolyzed to $p$-nitrophenol plus acetic acid. The reaction is detected at $348 \mathrm{~nm}$ [14]. $\mathrm{V}_{\max }, \mathrm{K}_{\mathrm{M}}$ and optimal $\mathrm{pH}$ were determined by this method. $\mathrm{V}_{\max }$ and $\mathrm{K}_{\mathrm{M}}$ values were determined from Lineweaver-Burk graph.

SDS-PAGE electrophoresis: The enzymes eluted from affinity column were controlled the purity by SDS gel electrophoresis [15]. Bovine erythrocyte carbonic anhydrase was purified by affinity chromatography and used as standard [19].

Molecular weight determination with gel filtration: For this purpose, Sephadex G-150 was incubated with distilled water at $90{ }^{\circ} \mathrm{C}$ for $5 \mathrm{~h}$ and was poured into column $(3 \mathrm{~cm} \times 70$ $\mathrm{cm})$. The column was balanced for $24 \mathrm{~h}$ with the buffer $(0.05$ $\mathrm{M} \mathrm{Na}_{3} \mathrm{PO}_{4}, 1 \mathrm{mM}$ dithiothreitol, $\mathrm{pH}=7$ ) until no absorbance at $280 \mathrm{~nm}$ was obtained. A standard solution of protein was added to the column and the standard graphics were obtained. The concentration of protein solution was $0.2 \mathrm{mg} / \mathrm{mL}$. The standard proteins and carbonic anhydrases were eluted under the same conditions in separate steps. The flow rate through the column was $20 \mathrm{~mL} / \mathrm{h} \mathrm{[15].}$

\section{RESULTS AND DISCUSSION}

In this study, carbonic anhydrase enzyme of bovine large intestine was prufied separetely as bonding weakly (peripheral) solved in cytoplasma (cytosolic) and bonded to membrane (integral) since it has not been characterized separetely yet. During purifiying of carbonic anhydrase enzyme, the technique 
of affinity chromatography was used. Protein contents in eluents were determined by measuring of absorbances in 280 $\mathrm{nm}$. However, determination of protein in solutions was defined by Coomassie Blue method. This method has more sensitivity, requires less time and is less reactive.

It was detected that the bovine large intestine carbonic anhydrase had a high hydratase activity. As shown in Table-1, specific activity for carbonic anhydrase was calculated for crude extract and purified enzyme solution. Purification was determinated 2865 fold for outer peripheral, 1490 fold for cytozolic, 2622 fold for inner peripheral, 2262 fold for integral.

Optimum $\mathrm{pH}$ values and $\mathrm{pH}$ intervals with activity were detected for large intestine enzymes, which are subtained purely. It seems that outer peripheral carbonic anhydrase enzyme's optimum $\mathrm{pH}$ was 6 and $\mathrm{pH}$ intervals with activity was 5.5-8. Cytosolic carbonic anhydrase enzyme'soptimum $\mathrm{pH}$ was 7.5 and $\mathrm{pH}$ intervals with activity was 5.5-8. However, inner peripheral and integral carbonic anhydrase enzymes' optimum pH was 7 and $\mathrm{pH}$ intervals with activity was 5.5-8 (Fig. 1). Similarly, carbonic anhydrase in bovine muscle, erythrocyte plasma membrane and bone showed optimum $\mathrm{pH}$ and $\mathrm{pH}$ interval activities $[10,20]$.

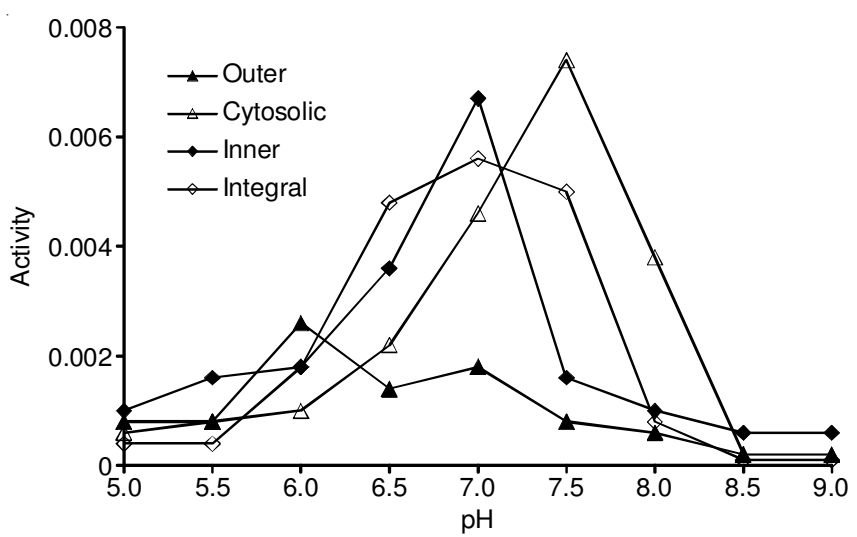

Fig. 1. Effect of pH on activity of carbonic anhydrase from bovine large intestine

Outer peripheral carbonic anhydrase enzyme's of large intestine had optimal temperature of $40{ }^{\circ} \mathrm{C}$ and cytosolic carbonic anhydrase enzyme's optimal temperature was $37^{\circ} \mathrm{C}$, However, this value was $35^{\circ} \mathrm{C}$ for inner peripheral and $25^{\circ} \mathrm{C}$ for integral carbonic anhydrase (Fig. 2). Range of temperature

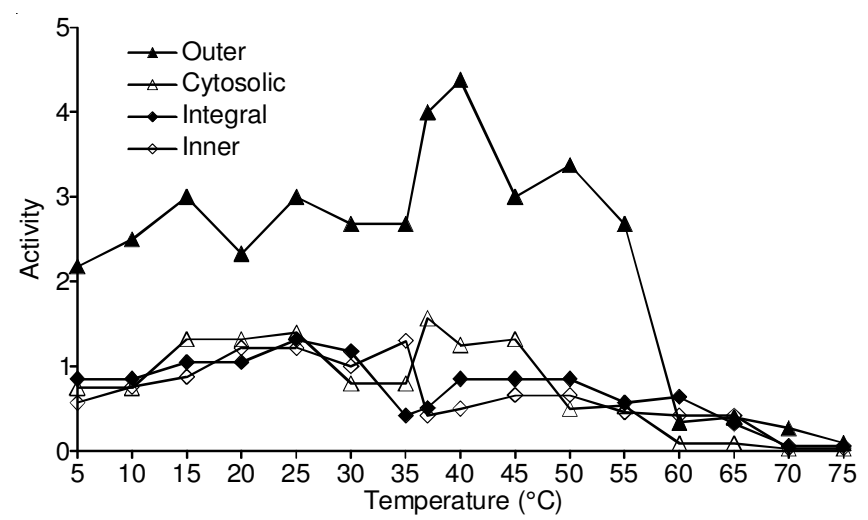

Fig. 2. Effect of temperature on the purified carbonic anhydrase enzymes from bovine large intestine

with activity was detected between $5-65^{\circ} \mathrm{C}$ for these 4 enzymes. Optimum temperature values were found the same or close to live body temperature. The optimum temperature for bovine bone marrow and other mammalian carbonic anhydrase are between $37{ }^{\circ} \mathrm{C}$ and $35^{\circ} \mathrm{C}[10]$.

SDS-polyacrylamide gel electrophresis was performed for determining subunits of enzymes that are purified from large intestine. Carbonic anhydrase enzyme that was purified from bovine erythrocyte for comparison (Fig. 3). Molecular weights of purified carbonic anhydrase enzymes from large intestine were detected by using gel filtration chromatography. Purified outer peripheral, cytosolic, inner peripheral and integral carbonic anhydrase enzymes of large intestine were formed of 2 subunits. Molecular weights of carbonic anhydrase enzymes were found 62.541 and 30.739 dalton for outer peripheral carbonic anhydrase, 53.606 and 30.739 dalton for cytosolic carbonic anhydrase, 60.221 and 28.086 dalton for inner peripheral carbonic anhydrase and 53.606 and 29394 dalton for integral carbonic anhydrase (Fig. 4). It is observed that present results are similar to molecular weights of the same species and organism $[3,12,13,21]$.

To conclude, the present results showed that carbonic anhydrase enzymes obtained from bovine large intestine were formed from monomer and dimer. While $\mathrm{V}_{\max }$ values of outer peripheral, cytosolic, inner peripheral and integral carbonic anhydrase enzymes which were purified from large intestine, were $1.06 \times 10^{-2}, 4.49 \times 10^{-3}, 5.45 \times 10^{-3}$ and $9.27 \times 10^{-3} \mu \mathrm{mol} /$ $\mathrm{L}$ min. $\mathrm{K}_{\mathrm{M}}$ values were found $1.901,0.51,0.55$ and $1.866 \mathrm{mM}$,

TABLE-1

CARBONIC ANHYDRASE ENZYMES FROM BOVINE LARGE INTESTINE

\begin{tabular}{|c|c|c|c|c|c|c|c|}
\hline & \multirow{2}{*}{$\begin{array}{l}\text { Volume } \\
(\mathrm{mL})\end{array}$} & \multirow{2}{*}{$\begin{array}{l}\text { Activity } \\
\text { (EU/mL) }\end{array}$} & \multicolumn{2}{|c|}{ Total activity } & \multirow{2}{*}{$\begin{array}{c}\text { Protein } \\
(\mathrm{mg} / \mathrm{mL})\end{array}$} & \multirow{2}{*}{$\begin{array}{c}\text { Specific } \\
\text { activity (EU/mg) }\end{array}$} & \multirow{2}{*}{$\begin{array}{l}\text { Purification } \\
\text { (fold) }\end{array}$} \\
\hline & & & EU & $\%$ & & & \\
\hline \multicolumn{8}{|l|}{ Outer peripheral } \\
\hline Homogenate & 300 & 9,4 & 2820 & 100 & 102 & 0.092 & - \\
\hline Purified enzyme & 30 & 33,75 & 1012.5 & 35.9 & 0.128 & 263.6 & 2865 \\
\hline \multicolumn{8}{|l|}{ Cytosolic } \\
\hline Homogenate & 250 & 6 & 1500 & 100 & 93.7 & 0.064 & - \\
\hline Purified enzyme & 25 & 11.3 & 282.5 & 18.8 & 0.1185 & 95.35 & 1490 \\
\hline \multicolumn{8}{|l|}{ Inner Peripheral } \\
\hline Homogenate & 300 & 3,6 & 1080 & 100 & 87.6 & 0.041 & - \\
\hline Purified enzyme & 25 & 10 & 250 & 23.1 & 0,093 & 107.5 & 2622 \\
\hline \multicolumn{8}{|l|}{ Integral } \\
\hline Homogenate & 300 & 3.9 & 1170 & 100 & 81.7 & 0.0477 & - \\
\hline Purified enzyme & 30 & 9.5 & 285 & 24.3 & 0.088 & 107.9 & 2262 \\
\hline
\end{tabular}




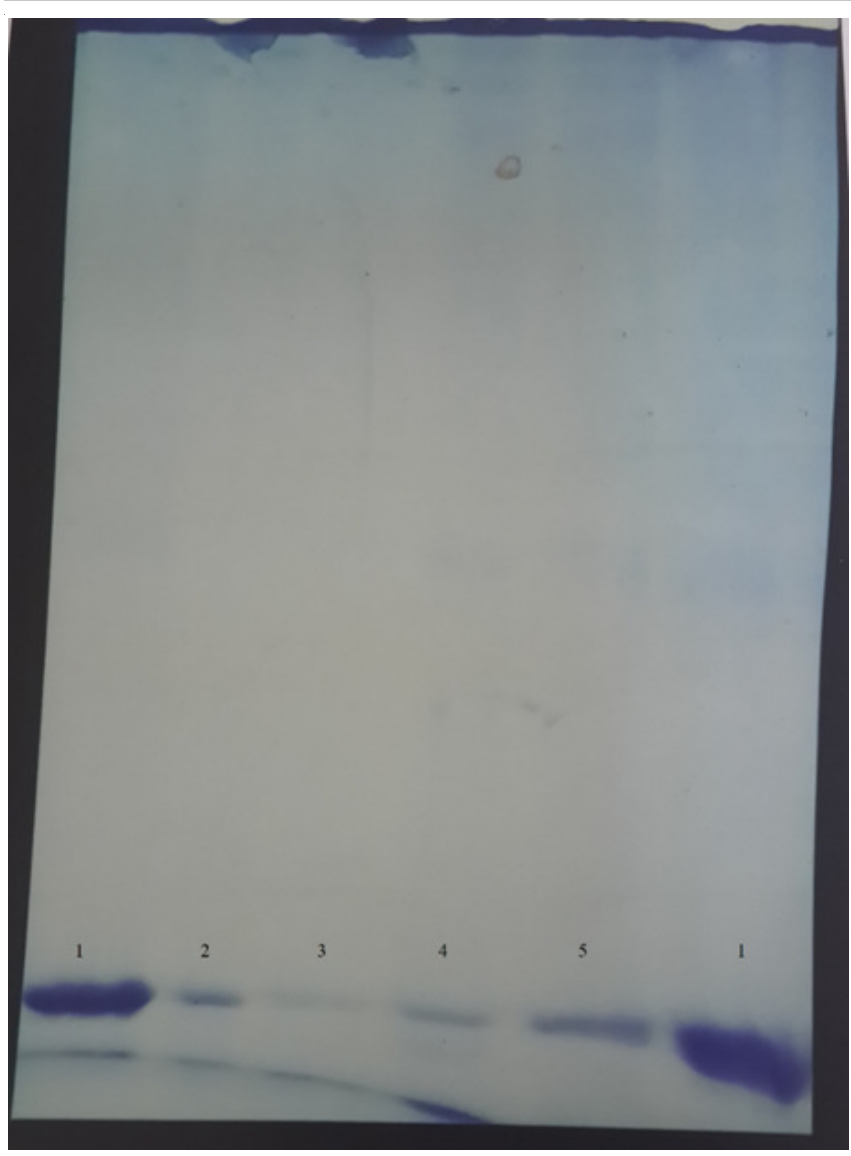

Fig. 3. SDS-PAGE electrophoretic pattern of large intestine carbonic anhydrase [BCA (1), carbonic anhydrase of large intestine (outer peripheral (2), cytosolic (3), inner peripheral (4) and integral (5), BCA (6)]

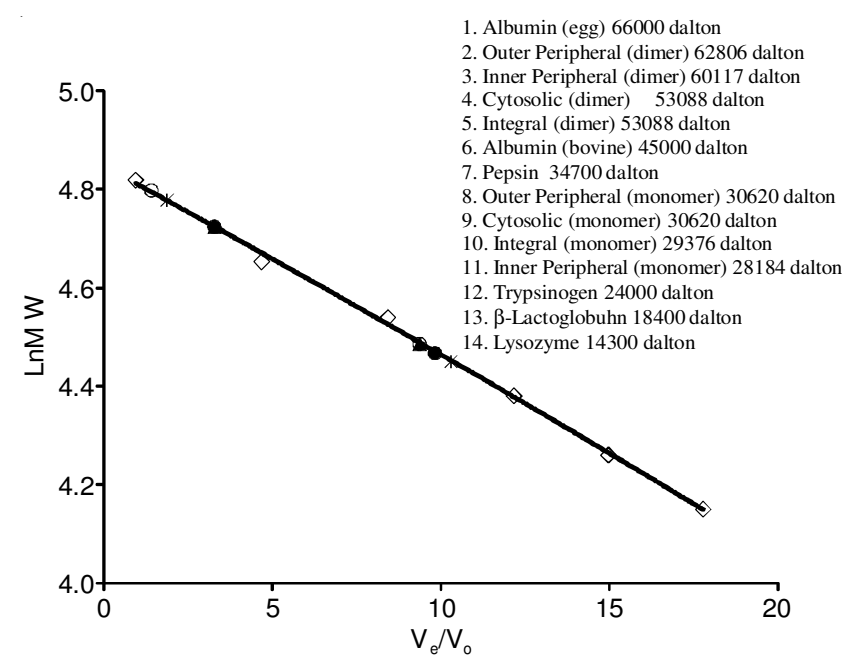

Fig. 4. Gel-filtration analysis of carbonic anhydrases from large intestine. The chromatography was on a Sephadex G-150 column in $0.05 \mathrm{M}$ sodium phosphate, $1 \mathrm{Mm}$ dithiothreitol, $\mathrm{pH} 7.0\left(\mathrm{~V}_{\mathrm{e}}=\right.$ elution volume, $\mathrm{V}_{\mathrm{o}}=$ column void volume)

respectively. It is observed that these values were different from each other. Membrane-bound isoenzymes have been thought to play an important role in the regulation of acid base balance, in expression in many cancer types, in buffering the extracellular space. Recent studies have shown that membrane-bound carbonic anhydrases are both able to bind to anion exchangers (AE proteins) forming metabolons and that such an interaction may facilitate anion transport activity [1]. It has been understood that the enzyme exists in a number of bovine tissues. Its high efficiency catalysis is fundamental to many biological processes, such as photosynthesis, respiration, $\mathrm{pH}$ homeostasis and ion transport [17]. However, there has been no study carried out on purification and characterization from bovine large intestine.

Defining large intestine carbonic anhydrase to bond forms seperately would be important for increasing the knowledge on meninge, especially with respect to peripheral and integral carbonic anhydrase which are related to membrane transport, being important in medicating gastrointestinal diseases.

\section{REFERENCES}

1. R. Riihonen, C.T. Supuran, S. Parkkila, S. Pastorekova, H.K. Väänänen and T. Laitala-Leinonen, Bone, 40, 1021 (2007); https://doi.org/10.1016/j.bone.2006.11.028.

2. T.H. Maren, Physiol. Inhibit. Physiol. Rev., 47, 595 (1967).

3. A.J. Tobin, J. Biol. Chem., 245, 2656 (1976).

4. D. Guillaume, T. Grisar and M. Vergniolle-Burette, Epilepsia, 32, 10 (1991); https://doi.org/10.1111/j.1528-1157.1991.tb05603.x.

5. R.A. Coulson and J.D. Herbert, Ann. N. Y. Acad. Sci., 429(1 Biology and C), 505 (1984); https://doi.org/10.1111/j.1749-6632.1984.tb12379.x.

6. T.H. Maren, Ann. N. Y. Acad. Sci., 429(1 Biology and C), 568 (1984); https://doi.org/10.1111/j.1749-6632.1984.tb12389.x.

7. Y. Demir, N. Demir, E. Bakan, O.I. Küfrevioglu and M. Gündogdu, Turk. J. Med. Sci., 26, 467 (1996).

8. O. Arslan, B. Nalbantoglu, N. Demir, H. Özdemir and Ö.I. Küfrevioglu, Turk. J. Med. Sci., 26, 163 (1996).

9. M.M. Bradford, Anal. Biochem., 72, 248 (1976); https://doi.org/10.1016/0003-2697(76)90527-3.

10. E. Tasgin, H. Nadaroglu, Y. Demir and N. Demir, Asian J. Chem., 21, 5117 (2009).

11. Y. Pocker and S. Sarkanen, Adv. Enzymol., 49, 149 (1979).

12. M.J. Carter, Biol. Rev., 47, 465 (2008); https://doi.org/10.1111/j.1469-185X.1972.tb01079.x.

13. J.A. Verpoorte, S. Mehta and J.T. Edsall, J. Biol. Chem., 242, 4221 (1967).

14. U.K. Laemmli, Nature, 227, 680 (1970); https://doi.org/10.1038/227680a0.

15. T. Goto, H. Shirakawa, Y. Furukawa and M. Komai, Br. J. Nutr., 99, 248 (2008); https://doi.org/10.1017/S0007114507801565.

16. E.E. Rickli, S.A.S. Ghazanfar, B.H. Gibbons and J.T. Edsall, J. Biol. Chem., 239, 1065 (1964).

17. R.E. Fleming, S. Parkkila, A.K. Parkkila, H. Rajaniemi, A. Waheed and W.S. Sly, J. Clin. Invest., 96, 2907 (1995); https://doi.org/10.1172/JCI118362.

18. N. Demir, Ö.I. Küfrevioglu, E.E. Keha and E. Bakan, Biofactors, 4, 129 (1993).

19. P. Engberg, E. Millqvist, G. Pohl and S. Lindskog, Arch. Biochem. Biophys., 241, 628 (1985);

https://doi.org/10.1016/0003-9861(85)90589-2.

20. Y. Demir, N. Demir, H. Nadaroglu and E. Bakan, Prep. Biochem. Biotechnol., 30, 49 (2000); https://doi.org/10.1080/10826060008544944.

21. A. Sharma, A. Bhattacharya and S. Singh, Process Biochem., 44, 1293 (2009); https://doi.org/10.1016/j.procbio.2009.07.022. 